\title{
Potential risk of MSMEs processing anchovies cluster in Lampung, Indonesia
}

\author{
FM Saty $^{1^{*}}$ and A Fitri ${ }^{1}$ \\ ${ }^{1}$ Departement of Food Agribusiness, Economics and Business, Politeknik Negeri \\ Lampung, Soekarno Hatta Street No. 10 Rajabasa, Bandar Lampung, Indonesia
}

*Corresponding author: fadila@polinela.ac.id

\begin{abstract}
This paper aims to analysis of potential risks in terms of capital, production, and marketing aspects at the SMEs center for salted fish manufacturing in Lampung. This research location was Pulau Pasaran Kota Karang, Teluk Betung, Bandar Lampung. The data was collected using questionnaires then processed. The research method is conducted by classifying the potential risk of SMEs, rating and predicate potential risk factors for MSMEs and establish a composite rating of potential risks of MSMEs. Based on 3 aspects of research, there is MSMEs no high and medium risk potency that is in capital aspect. Based on the production rating of the potential risks of MSMEs there are 7 MSMEs that have low risk potential, and 12 MSMEs have medium risk potential. Marketing aspect, there are 13 MSMEs with low risk potential and only 6 MSMEs with medium risk potential.
\end{abstract}

\section{Introduction}

MSMEs (Enterprises, Micro, Small and Medium Enterprises) have an important and strategic role in the national economy. In the business world in Lampung Province the existence of MSMEs still dominates. The 2016 Economic Census illustrates that the number of these businesses reached more than 770 thousand or 99,17 percent [1].

The development of MSMEs in Lampung Province increased by $60,25 \%$ in 2017. The development of MSMEs had an impact on employment, so that it also had an impact on gross domestic product. Although the increase was quite large, the results of several studies indicated that the sustainability and resilience of MSMEs was vulnerable to obstacles and risks.

The results of the UMKM study in Bandar Lampung [2] illustrate that the obstacles faced by business actors are the need for regulatory support from the government in increasing capital in addition to technological limitations. In the results of the UMKM study in Kudus [3] it describes that MSMEs have potential risks in capital, production, marketing. In the long-term condition, these obstacles can have an impact on business sustainability. Lack of mastery of technology, lack of human resources, even capital, hinder performance and there is no focus on business.

The results of studies in Indonesia and other countries also show a similar situation. Case studies of small and medium enterprises in Indonesia [4] and in Laos [5], face obstacles to performance growth due to lack of mastery of technology, lack of human resources, no focus on business. Apart from that, the government policy is not impartial for small entrepreneurs in Laos.

Bank Indonesia conducted a clusterization of potential MSME commodities in Indonesian regions. Based on the cluster, there are 20 centers for SMEs in 11 regions in Indonesia and Lampung Province is one of them that is the center. The center is the banana and anchovy chips industry [6]. The banana 
chips industry, which has been stagnant in the Mount Terang area and anchovies on Pasaran Island, has become one of the exporters to various regions in Indonesia and even abroad in Malasiya.

Pulau Pasaran is a fish processing center salty in Lampung. Salted fish is one of the processed fish products which is often consumed by Indonesian people. Besides the cheap price of salted fish is also easy to obtain. The production of salted fish originates from the catch of fishermen's sea fish in the form of fish which are usually sold directly to TPI (Fish Auction Place), then used by the community on Pasaran Island to be processed into salted fish. Salted fish is processed from sea fish in a way preserved traditionally.

The great potential on Pulau Pasaran has been developed, but not optimal. At the time of this pandemic, how can the sustainability of the business as a center for salted fish production last? So the potential risk to capital, production and marketing becomes a study of the sustainability of MSMEs.

\section{Material and Method}

The sample firms studied in this research was MSMEs in Pulau Pasaran. These samples were processed by using the probability sampling method with a purposive sampling technique to obtain the desired sample. Quantitative data analysis begins by performing descriptive analysis and graphical representation. This descriptive analysis is designed to collect information about real situations and describe the nature or current state at the time of the research. The results of the descriptive analysis are presented in the form of statistical summary tabulations based on the group of selected variables. In this study, the descriptive analysis presented is the profile of respondents, number of family dependents, demographics MSMEs.

Data analysis was carried out in 3 (three) stages, is:

1. Classification of the potential risks of each MSME,

2. Determination of the ranking and predicate of MSME factors based on the potential risks of each aspect that is the research variable,

3. Determination of the MSME risk potential composite rating based on the risk potential from the aspects of capital, production and market.

The classification of potential MSMEs risks based on aspects of capital, production and market are as follows:

a) Capital Aspects:

a. Potential risk is low if the source of capital is $100 \%$ own capital;

b. Medium potential risk if the source of capital consists of equity and debt from nonfinancial institutions;

c. The potential risk is high if the source of capital is $100 \%$ of the debt of the financial institution.

b) Production Aspects:

a. Potential low risk if the raw materials are obtained locally (Pulau Pasaran and its surroundings), and the production process is done manually;

b. Medium potential risks if the raw materials are obtained from local and local sources (both from Pasaran Island and its surroundings as well as from outside Pasaran Island), and the production process is carried out manually and technically;

c. Potential risks

c) Marketing Aspects:

a. Potential low risk if marketing is done offline;

b. Medium potential risk if marketing is combined offline and online;

c. Potential high risk if marketing is done online.

\section{Results and Discussion}

Pulau Pasaran is one of them island located on Rt 09 and Rt 10 LK II Kelurahan Kota Karang Teluk Betung Timur City District Bandar Lampung. Island Distance Market from downtown Bandar Lampung $5 \mathrm{Km}$. Pulau Pasaran has an area of 12 ha, and the number population of 265 households. Pulau Pasaran is a fish processing center salty in Lampung. Salted fish is one of the processed products fish that are often consumed by Indonesian society. Besides the price is cheap salted fish too 
easily obtained. The characteristic of these MSMEs is business management absence legal entity status, the absence of a sys financial records, executed with limited capital and expertise limited use of technology which is simple. The demographic characteristics of respondents are shown in Table 1 below that includes gender, the age of respondent, last education level, number of family responsibilities, capital and duration of the respondent's business establishment.

Tabel 1. Descriptive Statistic

\begin{tabular}{|c|c|c|c|}
\hline Variable & Category & $\mathrm{n}$ & $\%$ \\
\hline \multirow[t]{2}{*}{ Gender } & Male & 14 & 73,7 \\
\hline & Female & 5 & 26,3 \\
\hline \multirow[t]{4}{*}{ Age (year) } & $\leq 30$ & 3 & 21,1 \\
\hline & $31-40$ & 7 & 36,8 \\
\hline & $41-50$ & 6 & 31,6 \\
\hline & $>50$ & 3 & 10,5 \\
\hline \multirow[t]{3}{*}{ Education } & Primary school & 14 & 73,7 \\
\hline & Junior High School & 4 & 21,1 \\
\hline & Senior High School & 1 & 5,3 \\
\hline \multirow[t]{3}{*}{ Number of family responsibilities } & $<4$ & 2 & 10,5 \\
\hline & $4-7$ & 10 & 52,6 \\
\hline & $>7$ & 7 & 36,8 \\
\hline \multirow[t]{2}{*}{ Capital } & Owner's equity & 19 & 100 \\
\hline & Other parties & 0 & 0 \\
\hline \multirow[t]{4}{*}{ Business age (year) } & $\leq 10$ & 4 & 21,1 \\
\hline & $11-20$ & 7 & 36,8 \\
\hline & $20-30$ & 5 & 26,3 \\
\hline & $>30$ & 3 & 15,8 \\
\hline
\end{tabular}

The number of MSMEs processing encovy is 19 samples. Characteristics of the sample can be described in several categories among others based on gender. It shows male respondents hold $73,7 \%$ among all respondents with the remaining $26,3 \%$ of female respondents. Then, based on the last education, respondents with recent education, primary school-degree, and junior high school dominates with a percentage of $73,7 \%$ and $21,1 \%$, respectively. This shows the low level of education degree possessed by most enterpreneurs in processing ancovy in Pulau Pasaran and in consequence discourage the development of MSME sector in this area in terms of human resources.

Furthermore, the MSMEs that became the object of the average research has stood for more than five year. Average for business age of eighteen years. Based on duration of business life, most of MSMEs samples sustain more than 5 years which means the long-standing business experience has main role to keep the sustainability of their business. What is interesting is that the source of capital from this business comes from own capital.here are no other parties involved, such as banking or others. Finally, the sample of respondents in this study had an average age above 40 years.

Tabel 2. Potential Risk MSMEs

\begin{tabular}{ccccc}
\hline \multicolumn{1}{c}{ Variable } & Low Risk & Medium Risk & High Risk \\
\hline 1. & Capital aspect & 19 & 0 & 0 \\
\hline 2. & Production aspect & 7 & 12 & 0 \\
\hline 3. & Marketing aspect & 13 & 6 & 0 \\
\hline
\end{tabular}

The criteria for determining the ranking and predicate of factors based on the object of research are carried out by quantifying qualitative data on the potential risks of MSMEs based on aspects of 
capital, production and marketing. In Table 2 above, the following conclusions are obtained on the object of research:

a) Based on the capital aspect, all MSMEs are potentially low risk. This situation is because all business actors get their own capital

b) Based on the production aspect, there are 7 MSMEs with low risk potential, and 12 MSMEs with medium risk potential. Business actors get fish caught from nearby islands, but in certain seasons fishermen go outside the island to get fish.

c) Based on the marketing aspect, there are 13 MSMEs with low risk potential and only 5 MSMEs with medium risk potential. Some of the MSMEs players are selling directly to wholesalers in Java, North Sumatra, Kalimantan, Sulawesi and even to Malaysia. The use of online media has been carried out this year, namely by WhatsApp.

The results of the MSMEs composite ranking show that the potential risk of MSMEs in Pulau Pasaran is that 7 MSMEs have low potential risks and 12 MSMEs have moderate potential risks. The potential risks faced by anchovy processing business actors on the market islands are low and medium, this condition can be seen in the presence of a pandemic situation that does not show a decrease in production. The processing of anchovy is still running as usual. Production was not running due to weather. This sometimes erratic enemy greatly affects fish catches, so fishermen have to search for distant islands. This situation can affect the potential risk, which can be turned into a high initial.

\section{Conclusions}

The grouping of small and medium MSMEs in Pulau Pasaran, Kota Karang Teluk Betung Bandar Lampung, based on potential risks in terms of capital, production and marketing aspects, does not have high risk potential. The determination of the composite ranking for the potential risk of MSMEs, the potential risks of MSMEs in Pulau Pasaran, were 7 MSMEs had low risk potential and 12 MSMEs had medium potential risks.

\section{References}

[1] S Yeane Irmaningrum. MA 2016 Potensi usaha Mikro Kecil Provinsi Lampung (Badan Pusat Statistika Provinsi Lampung)

[2] Marlinda Apriyani,E Asliana,Fadila Marga Saty 2016 Tingkat Pendapatan dan Faktor-Faktor Penentu Pendapatan UMKM di Bandar Lampung J. Ilm. ESAI 10

[3] Alifiana, Mia A 2018 Analisis Potensi Risiko UMKM di Kabupaten Kudus Manaj. dan Bisnis Media Ekon. XVIII

[4] Hanggraeni D, Ślusarczyk B, Sulung L A K and Subroto A 2019 The Impact of Internal, External and Enterprise Risk Management on the Performance of Micro, Small and Medium Enterprises Sustainability 112172

[5] Southiseng, N. Walsh J 2010 Competition and Management Issues of SME Entrepreneurs in Laos: Evidence from Empirical Studies in Vientiane Municipality, Savannakhet and Luang Prabang Asian J. Bus. Manag. 2

[6] Bank Indonesia 2019 Profile Sentra UKM Bank Indonesia. 